\title{
The Role of Management Games in Mapping Learning Styles to Elements of Business Know- How Acquisition: A Case Study
}

\author{
Magdy M. Kabeil \\ University of Sharjah, UAE
}

kabeil@sharjah.ac.ae

\begin{abstract}
The main purpose of this paper is to assess the role of management games in mapping students' preferable learning styles to elements of business know-how acquisition in a specific environment. A management game is developed to cover five functional areas of a manufacturing company: marketing, research and development, human resources, production and inventory, and finance.

Elements that advance the acquisition of business know-how are identified, embedded in the game, and evaluated by students with different preferences of learning style. The investigation confirms the existence of a significant role of the game in mapping student's preferable learning styles to elements for acquisition of business know-how. The most impact of the game is on the Dynamics and Intensity e lements of business know-how acquisition for most students.
\end{abstract}

The vast majority of students who have participated in the game are active (79\%), sensing (76\%), and visual $(81 \%)$ learners who believe that the game enhanced their capability of business knowhow acquisition. Students who are global learners and support the use of the game are only $45 \%$ of the sample; however, they still represent a valuable portion that may include the most inventive thinkers among the student population.

Keywords: Management Games; Business Simulation; Bus iness Know-How Acquisition; Learning Styles; Business Education.

\section{Introduction}

Strategic decision making concerns larger personnel groups nowadays than before (Lainema \& Lainema, 2007). Employees at lower levels of the organization are participating in decision making with more impact on forming the strategy of the organization (Kabeil, 2008). More than twelve years ago, Senge (1997) predicted that leadership would be more and more distributed among diverse individuals and teams who share the responsibility for creating the organization's

Material published as part of this publication, either on-line or in print, is copyrighted by the Informing Science Institute. Permission to make digital or paper copy of part or all of these works for personal or classroom use is granted without fee provided that the copies are not made or distributed for profit or commercial advantage AND that copies 1) bear this notice in full and 2) give the full citation on the first page. It is permissible to abstract these works so long as credit is given. To copy in all other cases or to republish or to post on a server or to redistribute to lists requires specific permission and payment of a fee. Contact Publisher@InformingScience.org to request redistribution permission. strategy.

The diverse involvement in decision making means that the organizational processes need to be understood by wider groups of employees. Employees need overall knowledge to complement their function-specific skills. The challenge is to raise the level of understanding of all employees to the domain of business know-how. The business 
know-how is defined as a combination of knowledge and several different skills that give an overall view of the functioning of a business organization as a whole (Ghoshal, Bartlett, \& Moran, 1999). However, the learning process of business, like many other learning domains, has major deficiency of oversimplification (Hakkarainen, Palonen, Paavola, \& Lehtinen, 2004). One serious kind of oversimplification is looking at a concept from just one perspective. While business work is increasingly becoming a team and group effort, business schools are looking for new approaches to promote the potential strength of collaboration in business education. One way of doing it is management game.

Management game is often seen as a vehicle, which is used for helping to visualize and rehearse strategy in holistic approach. It makes it possible to sketch the organizational cause-and-effect relationships and to communicate more clearly with structures that translate decisions into actions (Morecroft, 1999).

The use of management games in business education has been documented through a series of surveys (Faria, 2001; Gilgeous \& D'Cruz, 1996). Lainema and Lainema (2007) consider management game as one of the critical learning elements for advancing acquisition of business know-how. Connolly and Stansfield (2007) demonstrate the use of management games in elearning. Benbunan-Fich (2002) and Hoffman (2003) show some statistics on the impact of using management games on education and training. Moores and Chang (2001) and Martin (2000) give examples of business games that are developed to support the teaching of management information systems. Stolk (2001) demonstrates the use of management games in crisis management. Doyle and Brown (2000) show how they use a business management game to teach applied skills and the benefits and the challenges of using student teams from multiple countries.

Faria (2001) found that $65.7 \%$ of schools accredit by the AACBS (Association to Advance Collegiate Business Schools) used a game in their strategic management courses and instructors devoted from $2.0 \%$ to $80.0 \%$ of their class time to the game they were using, with $23.8 \%$ being their average class time usage. For that work, the instructors based $25.1 \%$ of their course's grade on the game. They also reported that games were the most effective way to teach strategic management.

The main purpose of this paper is to assess the role of management games in mapping elements of business know-how acquisition to different learning styles in a specific environment. The business education environment is of the College of Business Administration, University of Sharjah, UAE (http://www.sharjah.ac.ae) where a management game is developed for this purpose. The main approach is to identify the learning elements for advancing acquisition of business knowhow in a specific environment, to investigate the learning style preferences of business students in the given environment, and to measure the perspectives of students on the impact of the game on advancing the ir capability of business know-how acquisition.

\section{The Case Management Game}

The game used in this study is Strategic Management Game (SMG), which was developed by the author for this purpose. It is a simple web-based business game based on a simulation of real world company produces tractors and trailers. Players take the role of top management where each syndicate represents a group of managers employed by a company and companies compete against each other in real-time. The game is played by up to 5 syndicates each consists of from 2 to 5 players. The game is played over 5 periods, each taking about 20 minutes, with 4 short breaks in between and a central discussion session at the end. Each period of the game represents a year of operations and all teams start the game with the same resources and information.

Each syndicate is responsible for planning all aspects of its operations in order to arrive at the end of the fifth period (year) to the best result. The main areas concerned are marketing, research and 
development, human resources, production and inventory, and finance of two complementary products: tractors and trailers.

At the start of each period syndicates are issued with information showing the results of the previous year's activities together with further information to enable them to decide their operating policy for the forthcoming period. At the end of each period, each syndicate completes and submits a decision form showing their decisions for that period. The simulation plays out dynamically, based on all partic ipant decisions.

The aim of each syndicate is to optimize their performance measured by the performance indicator of the total Business Value (BV) scored for improvements in finance, technology, human resources, and inventory by the end of the fifth period. Other companies' assets are assumed constants within the time frame of the game.

\section{Rules of Research and Development}

All syndicates start with level 1 of tractor technology and type 1 of trailer technology. Syndicates may choose to put money into research and development (R \& D) during years 1-4 in an attempt to develop levels 2 and 3 of tractor technology and types 2 and 3 of trailer technology. No R \& D may take place in year 5 .

Development of level 2 of tractor technology must be completed before development of level 3 of tractor technology is commenced and, similarly, type 2 of trailer technology, must be successfully developed before expenditure can be initiated on developing type 3 trailers.

$\mathrm{R} \& \mathrm{D}$ is planned in one year cycles. Syndicates state on their decision form the amount they wish to-allocate to each R \& D project in any year and the information forms issued by the umpire for the following year's operations show any projects that have been successful. Once a project to develop the level 2 tractors or type 2 trailers has been successful, syndicates may, in the following year, either commences R \& D for the level 3 tractors or type 3 trailers, or, they may decide to delay or opt out of any further R \& D for tractors or trailers.

There are certain rules governing the expenditure incurred on any R \& D project. In the first year of a particular project, any amount of money may be spent, but in subsequent years the rule is as follows: if the previous year's R \& D has failed then a syndicate may opt to discontinue the project and loose all previous investments in the project; or the project may be continued (except in year 5), and half of the amount spent on the project in the previous years is added to the current expenditure on the project to give the "Investment Level" of current year on the project.

The probability that an $\mathrm{R} \& \mathrm{D}$ project will be successful is calculated from Figure 1 as follows: for the first year of a particular project take the annual expenditure as the "Investment Level"
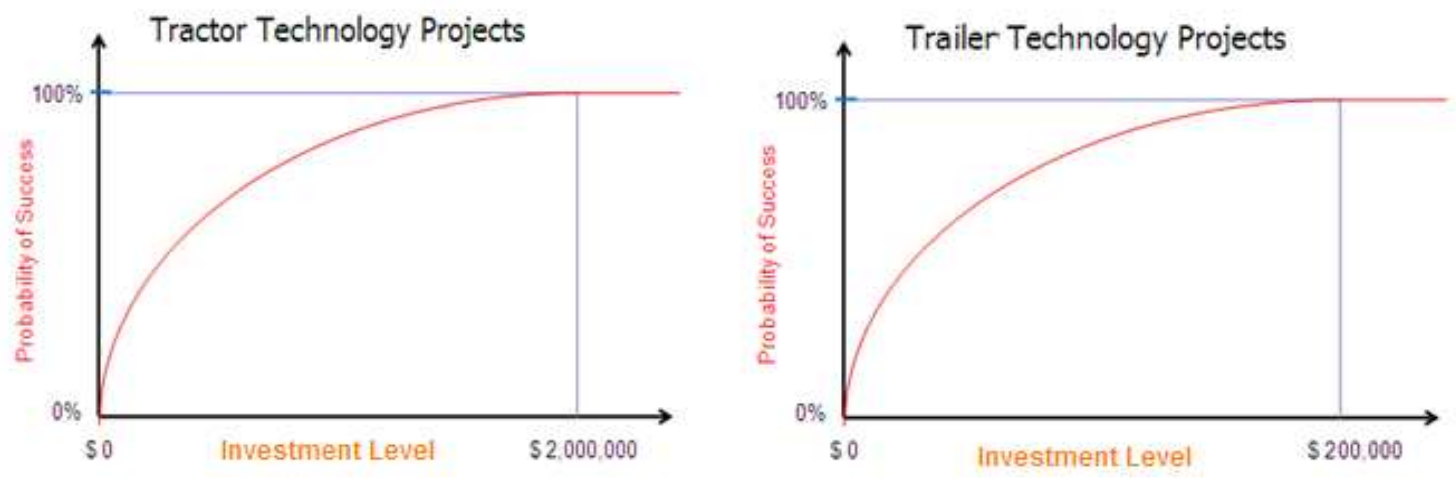

Figure 1: Probability of Success of R \& D Projects. 
shown on the curve and then read off the corresponding probability of success. In subsequent years take as the "Investment Level" the amount spent on the project in the current year, plus half of previous year's expenditure if the project was not successful.

\section{Rules of Production and Inventory}

Subject to financial and manpower limitations there is no restriction on the number of tractors/trailers produced in any year. However, those which are surplus to market requirement and market share have to be stored against future requirement and incur annual storage charges. No tractor can be sold alone without at least one trailer per tractor. The costs of production, less labor costs which are covered in the next section, are as depicted in Figure 2.

\begin{tabular}{l|c|c|c}
\hline & Production Cost (\$) & Manpower & Price (\$) \\
\hline Tractor_Level1 & 60,000 & 6 Man Month & 100,000 \\
\hline Tractor_Level2 & 50,000 & 6 Man Month & 150,000 \\
Tractor_Level3 & 40,000 & 6 Man Month & 200,000 \\
Trailer_Type1 & 12,000 & 2 Man Month & 20,000 \\
Trailer_Type2 & 10,000 & 2 Man Month & 40,000 \\
Trailer_Type3 & 8,000 & 2 Man Month & 60,000 \\
& & $\downarrow$ & \\
\multicolumn{2}{l}{ - To produce 1 tractor requires 6 man months (0.5 man year). } \\
\hline
\end{tabular}

Figure 2: Costs and Prices of Production.

All storage costs are deducted from the budget of the next year. Tractor storage cost is $\$ 10,000$ / year and trailer storage cost is $\$ 2000$ / year

\section{Rules of Human Resources}

All Syndicates start with an initial labor force which must be built up during the game period. Initial force of skilled manpower is 100 persons. Salary of skilled person is $\$ 25,000$ per annum. Salary of administration staff is half the total salaries of all skilled persons. If a skilled person is excluded from production, she/he can train 5 recruits to be skilled persons. Training period is one year. Salary of a trainee is $\$ 10,000$ per annum. Surplus manpower may be discharged at the beginning of any year but must be paid redundancy pay of $\$ 15,000$ per person discharged. The productivity is 2 tractors/person/year or 6 trailers/person/year.

\section{Expected Market Requirements}

Expected market requirements for the 5 years of the game are: 250, 600, 1250, 1450, 1500 tractors in addition to at least 1 or more trailers with each tractor. A syndicate may store extra tractors for next years. The maximum number of competitors in the market is 5 . The market share is a function of relative advertising expenditures as described in the following section. Figure 3 illustrates the pattern of market growth over the 5 years of the game. 


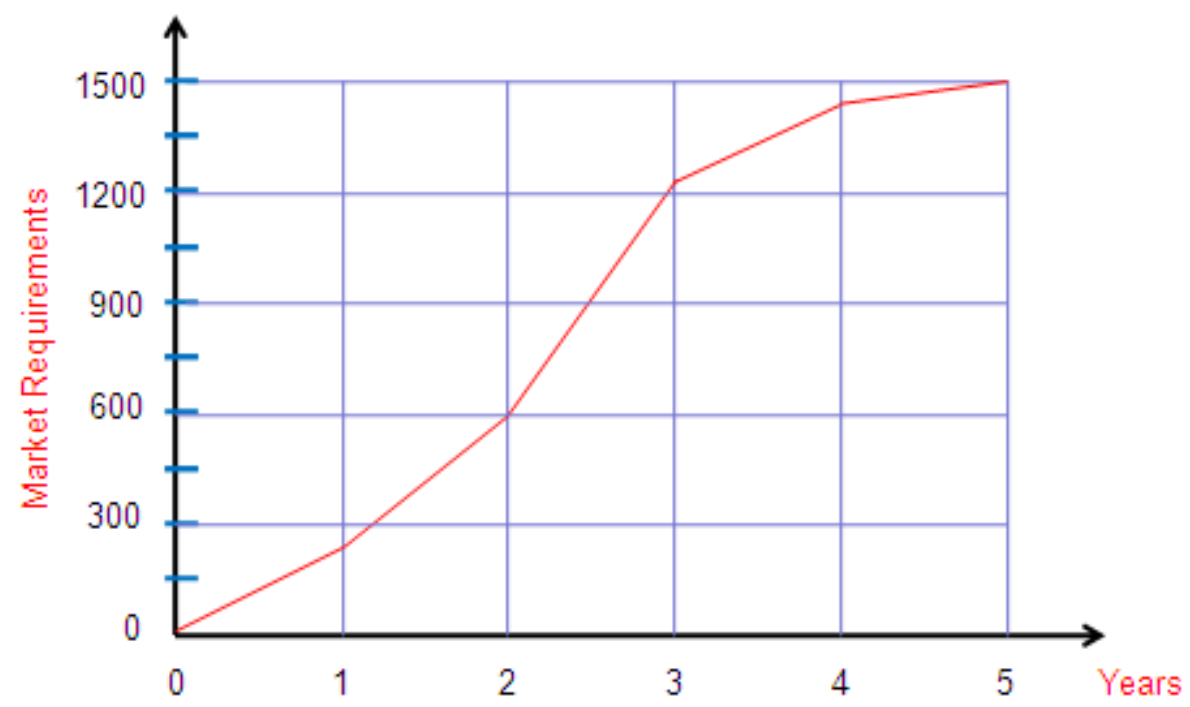

Figure 3: Expected Market Require ments.

\section{Rules of Market Share}

Market share is measured each year of the game based upon the level of advertising expenditures relative to the average advertising expenditure of all syndicates in the year. The minimum market share of any syndicate is $10 \%$ and the maximum share of any of them is $60 \%$. Figure 4 illustrates the market share as a function of the relative advertising expenditures. In the first period (year) of the game, each syndicate does not know the advertising expenditures of other syndicates. In every subsequent period (year) of the game, each syndicate can figure out the pattern of advertising expenditures of other syndicates in previous years.

\section{Expected Market Share}

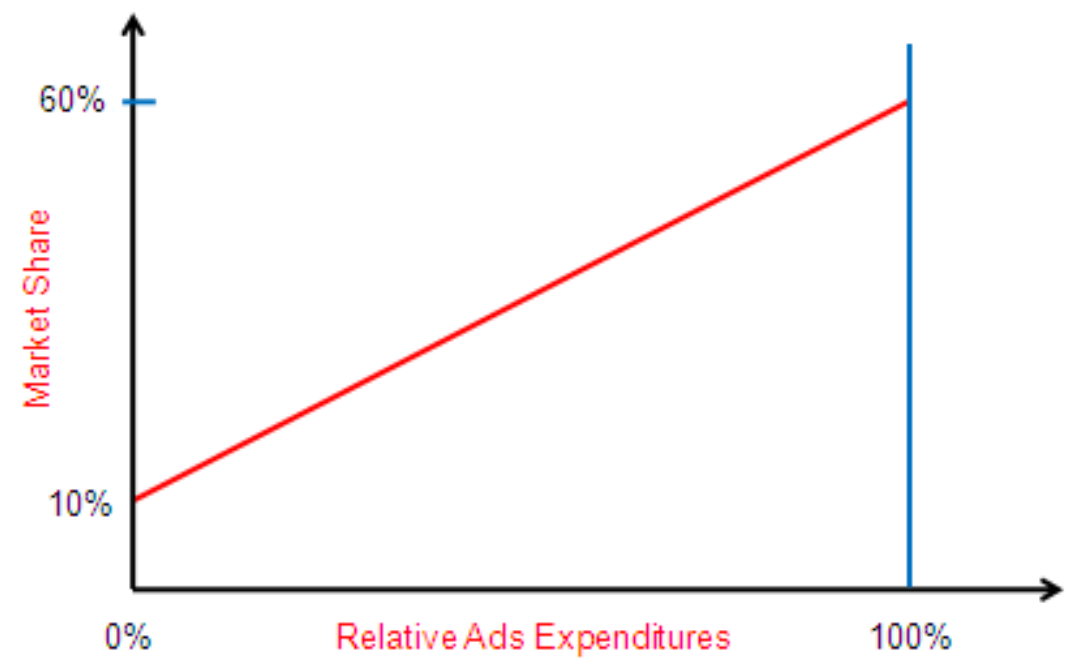

Figure 4: Expected Market Share. 


\section{Rules of Finance and Penalties}

Each syndicate will start with the same annual gross budget which will be notified on the decision form at the start of year 1. The budget of next years will be increased or reduced according to the syndicate performance. Net budgets are dependent on penalties incurred by individual syndicates in the preceding year as follows:

- $\quad$ Annual Budget $=$ Last Budget + Profit - Penalties .

- $\quad$ Profit $=$ Total Sales - Fixed Cost - HR Costs - Production Costs - Storage Cost - Ads Expenditures - R\&D Expenditures - Loans Cost.

- Loans Cost: $=15 \%$ of the loan/year

- Penalties of late submission of decis ion form $=\$ 5000 /$ minute.

- $\quad$ Value of the year $=$ Budget + Profit - Penalties

\section{Running the Game}

The SMG is implemented through a wireless Intranet as a learning lab. The main elements that integrate this learning lab are: the management game network, an umpire (instructor), syndicates, and observers. The spirit of this learning lab is to support active experimentation and inquiry where every participant surfaces and tests her/his mental models with others and make them explicit. Through this process can emerge a shared understanding of key assumptions and interrelationships. The emphasis on mental models is because they define behaviors and represents the business knowledge "Know-how and Know-why" (Kim, 1993).

The management game starts after the students having completed 81 credit hours of business courses. Each syndicate nominates a syndicate coordinator. Syndicate coordinator is responsible to coordinate activities within the group, to ensure adherence to the time frame developed by each syndicate, to communicate operation issues to the umpire, and to ensure the timely delivery of decisions.

Syndicates are introduced to the game through the scenario, which is a short description of where they are and what the company status that they will be coping with. This is shown by means of visual images and text that appear on the computer screen. The scenario also makes reference to what they will be doing during play, the objectives, their main roles, and performance criteria.

During the simulation, a syndicate must analyze each situation and make the best decision according to its tacit knowledge. Some situations just involve concepts issues and others require calculations, results interpretations, and application of tools, models and methods. While the simulation is running, the syndicates can consult the documents included in their class notes and decision support modules of the game.

SMG provides immediate feedback about each syndicate's decision. First, it tells if the decision was correct or incorrect and second, it provides additional information related to the decisions rational in the particular situation. This feedback enhances the learning process, even if the decision was right or wrong. In this manner, participants learn instantaneous ly by knowing the effects of their decision.

The last activity of the management game lab is the closing debriefing session. This session is focused on participants' performance in the game. Its aim is to help participants connect the know ledge and skills developed in the simulation to the corresponding real-life situation (Vincent and Vissers, 2004). Additionally, all syndicates have to make a brief presentation regarding their decisions and its consequences, their learning during the simulation, and the ir opinion about the game. 


\section{The Case Management Game in Support of Business Know-How Acquisition}

Business know-how is defined as the overall understanding of how business organizations function to achieve the business goals set by the top management (Lainema \& Lainema 2007). This overall understanding includes the ability to make informed decisions that lead to objective outcomes. A central capability in business know-how is the ability to optimize the whole instead of sub-optimizing functions and to work in complex decision-making domains with imperfect information. Examples of imperfect information in SMG are the market requirements, market share, and both advertising expenditures and levels of production of competitors.

Traditionally, business know-how has been examined as a competence based on individual dispositions rather than focusing on relations between individual skills and the dynamic functioning of business (Hakkarainen et al., 2004). Work in organizations is increasingly becoming structured in teams and groups supported by technology, which is reflected in the SMG.

Competence is based on the collaborative expertise of teams. Hakkarainen et al. (2004) call for networked expertise, which means "higher-level cognitive competencies that arise, in appropriate environments, from sustained collaborative efforts to solve problems and build knowledge together" (p. 9). Teams naturally integrate performance and learning, and the learning is cumulated into a collective know ledge-base (Katzenbach \& Smith, 1993). Team learning is more than the sum of all individual learning: it is collective learning (Simons et al., 2003).

The experiential nature, intens ity and motivational aspects of SMG that enhance learning through group interaction, would make the learning experience superior to other learning activities (Lainema \& Lainema 2007). The dynamic and authentic learning environment in SMG provides a self-directed learning experience, where instructors act as facilitators and group discussions bring out the tacit know ledge of the members of syndicates. This learning setting matches the challenge many organizations are facing (Nonaka, 1994).

Elements that advance the acquisition of business know-how are identified as empowerment, dynamics, validity, intensity, holistic approach, and collective experience (Lainema and Lainema 2007). These elements are embedded in the SMG used in this research as illustrated in Table 1.

\begin{tabular}{||l||l||}
\hline \multicolumn{2}{|c||}{ Table 1: Elements of B us iness Know-How Acquisition in SMG } \\
\hline \hline $\begin{array}{c}\text { Elements of Business } \\
\text { Know-How Acquisition }\end{array}$ & \multicolumn{1}{c||}{ SMG Support } \\
\hline \hline Empowerment & $\begin{array}{l}\text { The syndicates are responsible for managing the ir company and } \\
\text { making independent decisions. Measures of success of a com- } \\
\text { pany in the game are based on how the syndicate makes online } \\
\text { decisions. }\end{array}$ \\
\hline \hline Dynamics & $\begin{array}{l}\text { The syndicates form a strategy and make the decisions regarding } \\
\text { business functions. The consequences of their decisions are visi- } \\
\text { ble immediately. A syndicate's decisions in a year affect its status } \\
\text { in the next year as well as the market that all syndicates deal } \\
\text { with. }\end{array}$ \\
\hline \hline
\end{tabular}




\begin{tabular}{||l||l||}
\hline Validity & $\begin{array}{l}\text { Transparent business transactions and business processes are il- } \\
\text { lustrated in an authentic manner and business processes are tai- } \\
\text { lored according to real processes. }\end{array}$ \\
\hline \hline Intensity & $\begin{array}{l}\text { The game is clock-driven and dynamic. A real-time-operated } \\
\text { game model provides a sense of urgency to the decision-making. } \\
\text { The actions results of other syndicates are visible in real time. }\end{array}$ \\
\hline \hline Holistic Approach & $\begin{array}{l}\text { The game provides a holistic view on business operations. Each } \\
\text { team must handle several dynamic business transactions, and face } \\
\text { non-linearity and ill-structured decis ion-making problems. }\end{array}$ \\
\hline \hline Collective Experience & $\begin{array}{l}\text { Decision-making in syndicates of two to five participants forces } \\
\text { the participants to reason and justify their views to the others. } \\
\text { Formulating and carrying out a strategy is a joint effort during } \\
\text { which the team members share their expertise and externalize } \\
\text { their mental models. The syndicates' collective learning produces } \\
\text { the shared views and goals according to which they run their } \\
\text { company. }\end{array}$ \\
\hline
\end{tabular}

\section{Mapping Learning Styles to Elements of Business Know-How Acquisition}

A variety of measures have been used to characterize learning styles for students in general, but the literature contains little information specific to the field of business (Dee et al. 2002; Graf \& Lin, 2008). In this research, Felder's Index of Learning Styles (Felder, 1988) is utilized to investigate the learning style preferences of business students at UOS. The reason behind choosing the Index of Learning Styles indicator is that it is available for free on the internet, also, because of the considerable amount of available literature on the reliability and validity of the instrument. The goal is to identify the weight of using the management game as a viable method to accommodate the widest possible variety of learning styles toward each element of business know-how acquisition.

\section{Index of Learning Styles}

Felder's index of learning styles is an instrument that was developed to determine the different dimensions of learning. Four dimensions of learning style preferences are defined. Within each dimension there are two opposing poles as illustrated in Table 2. The index of learning styles summarizes the self reported preferences concerning whether:

1) the manner of processing information, actively or in a reflective manner;

2) the manner of receiving information, visually or verbally;

3) the type of data, sensory or intuitive; and

4) the manner of progress towards understanding, in a sequential or a global (holistic) manner.

The reported preference of each side of each dimension is measured as a score from 1 to 11 . 


\begin{tabular}{|c|c|c|}
\hline \multicolumn{3}{|c|}{ Table 2. Dimensions of Felder Learning Styles. } \\
\hline $\begin{array}{l}\text { Dimension 1: proc- } \\
\text { essing information }\end{array}$ & $\begin{array}{c}\text { Active } \\
\text { (Learn by doing }+ \text { In group) }\end{array}$ & $\begin{array}{c}\text { Reflective } \\
\text { (Independent }+ \text { Thoughtful) }\end{array}$ \\
\hline $\begin{array}{l}\text { Dimension 2: re- } \\
\text { ceiving information }\end{array}$ & $\begin{array}{c}\text { Sensor } \\
\text { (Facts, Data, Reality) }\end{array}$ & $\begin{array}{c}\text { Intuitive } \\
\text { (Ideas, Abstracts, Possibilities, } \\
\text { Theories \& Models) }\end{array}$ \\
\hline $\begin{array}{l}\text { Dimension 3: type } \\
\text { of data }\end{array}$ & $\begin{array}{c}\text { Visual } \\
\text { (Pictures, Diagrams, Films, } \\
\text { Apparatus) }\end{array}$ & $\begin{array}{c}\text { Verbal } \\
(\text { Written + Formulas })\end{array}$ \\
\hline $\begin{array}{l}\text { Dimension } 4 \text { : pro- } \\
\text { gress towards under- } \\
\text { standing }\end{array}$ & $\begin{array}{c}\text { Sequential } \\
\text { (Steady Progress, Detailed } \\
\text { Analysis, One at a Time) }\end{array}$ & $\begin{array}{c}\text { Global } \\
\text { (Holistic, Big Picture, Creative } \\
\& \text { Synthesis) }\end{array}$ \\
\hline
\end{tabular}

\section{Measuring Felder's Index of Learning Styles}

The online questionnaire, which is available at http://www.engr.ncsu.edu/learningstyles/ilsweb.html, was used for measuring Felder's Index of Learning Styles. It consists of 44 questions asking the user if she/he understands something better after she/he tries it out or thinks it through, if she/he would rather be considered realistic or innovative, and other questions that measure the four dimensions of the index. After getting the results from the online questionnaire, students were given a paper questionnaire to record the score she/he got on each dimension of Felder's Index along with her/his perspective on the impact SMG has on each element of the business know-how acquisition measured on 5 points Likert scale.

The questionnaires were administered to senior business administration students (completed 81 credit hours of business courses) who had been taking the course "Decision Support Systems" and who participated in SMG as an assessment tool of the course. The size of the student sample who participated in the delivered response was 24 students.

In general, we found out that the percentage of the students who believe that the game has positive impact on all elements of the business know-how acquisition is $80 \%$ and the percentage of the students who believe that the game has a positive impact on any one element of the business know-how acquisition is $100 \%$ of the sample. However, these values are different for students of different learning style indexes as depicted in Table 3. 


\begin{tabular}{|c|c|c|c|c|c|c|c|c|}
\hline \multicolumn{9}{|c|}{$\begin{array}{l}\text { Table 3: Weighted Average of SMG Impact on Elements of } \\
\text { Business Know-How Acquisition for Different Learning Styles }\end{array}$} \\
\hline $\begin{array}{r}\text { Relative Weighted } \\
\text { Average* }\end{array}$ & $\stackrel{0}{\stackrel{0}{0}}$ & 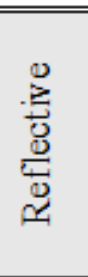 & $\begin{array}{l}\bar{b} \\
\bar{D} \\
\bar{D} \\
\bar{D}\end{array}$ & 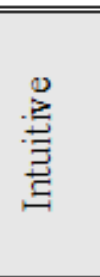 & $\begin{array}{l}\vec{\sigma} \\
\overrightarrow{\vec{v}} \\
\end{array}$ & $\begin{array}{l}\bar{J} \\
\frac{0}{0} \\
>\end{array}$ & 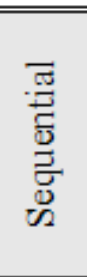 & $\begin{array}{l}\bar{\sigma} \\
\frac{0}{0} \\
0\end{array}$ \\
\hline Average*** & 0.79 & 0.21 & 0.76 & 0.24 & 0.81 & 0.19 & 0.54 & 0.46 \\
\hline Empowerment & 1.9 & 1.1 & 1.7 & 1.4 & 1.6 & 0.4 & 1.2 & 1.8 \\
\hline Dynamics & 2.0 & 1.3 & 1.8 & 1.4 & 1.7 & 1.1 & 1.5 & 1.9 \\
\hline Validity & 1.8 & 0.2 & 1.6 & 0.8 & 1.3 & 0.3 & 0.6 & 1.8 \\
\hline Intensity & 1.9 & 1.3 & 1.9 & 1.4 & 1.8 & 1.6 & 1.1 & 1.9 \\
\hline Holistic Approach & 1.7 & 0.9 & 1.6 & 1.2 & 1.5 & 1.4 & 1.0 & 1.7 \\
\hline Collective Experience & 1.6 & 0.6 & 1.4 & 1.1 & 1.5 & 1.2 & 0.8 & 1.5 \\
\hline
\end{tabular}

* Relative Weighted Average $=\sum$ Scores on the Coordinate $/\left(\sum\right.$ Scores on the Left Coordinate + $\sum$ Scores on the Right Coordinate).

** Impact Weighted Average $=\sum$ Impact Weight / No of Values.

\section{Analysis of Results}

The investigation confirms the existence of a significant role of SMG in mapping different learning styles to the stated elements of business know-how acquisition. These can be summarized as follows:

1. The percentage of students who believe that the game has a positive impact on all elements of the business know-how acquisition is $80 \%$.

2. The percentage of students who believe that the game has a positive impact on any one of these elements is almost $100 \%$.

3. Most students of the sample are Active in processing information, Sensor in receiving information, and $\mathrm{V}$ isual in preferable type of data.

4. Regarding of the manner of progress towards understanding, students are more Sequential than Global learners.

5. Students who are Active learners believe that the game has the most impact on the Dynamics element of business know-how acquisition and the next impact on Empowerment and Intensity.

6. Students who are Sensor learners believe that the game has the most impact on the Intensity element of business know-how acquisition and the next impact on Dynamics. 
7. Students who are Visual learners also believe that the game has the most impact on the Intensity element of business know-how acquisition and the next impact on Dynamics.

8. Students who are Global learners represent only $46 \%$, but they may include the most inventive thinkers among the student population. They believe that the game has the most impact on both Dynamics and Intensity e lements of business know-how acquisition.

9. In general, the results show that the game has significant impact on the Dynamics and Intensity elements of business know-how acquisition for most students of the sample.

However, it must be pointed out that this investigation does not take into account other factors such as gender, age and former internship or work experience. The research will be expanded with larger sample size in several subsequent semesters to study the pattern of improvement over time.

\section{Conclusions}

The results show that management games can be used as an effective tool for mapping different learning styles to elements of business know-how acquis ition. In the presented case study, a Webbased management game (SMG) is developed as a business simulation of a manufacturing company that produces two complementary products. The main areas concerned in the game are marketing, research and development, human resources, production and inventory, and finance. The game is played over five periods, each represents a year of company operations and all syndicates start the game with the same resources and information.

Elements that advance the acquisition of business know-how are identified as empowerment, dynamics, validity, intensity, holistic approach, and collective experience. These elements are embedded in the SMG and evaluated by students with different preferences of learning style.

After getting the results from the Felder's online questionnaire, students were given a paper questionnaire to record the score she/he got on each dimension of Felder's Index along with her/his perspective on the impact SMG has on each element of the business know-how acquisition measured on 5 point Likert scale.

The investigation confirms the existence of a significant role of SMG in mapping student's preferable learning styles to elements of business know-how acquisition. Most students of the sample are Active in processing information, Sensor in receiving information, and V isual in preferable type of data. Regarding of the manner of progress towards understanding, students are more Sequential than Global learners.

In general, the results show that the game has significant impact on the Dynamics and Intensity elements of business know-how acquisition for most students of the sample.

The main limitations of the study are the sample size and the time frame. Future research will be conducted with larger sample size in several subsequent semesters.

\section{References}

Benbunan-Fich, R. (2002). Imp roving education and training with information technology. Communications of the ACM, 45(6), 94-99.

Connolly, T. \& Stansfield, M. (2007). Frome-learning to games-based e-learning: using interactive technologies in teaching an IS course. International Journal of Information Technology \& Management, 6(2-4), 188-207.

Dee, K. C., Nauman, E. A., Livesay, G. A., \& Rice, J. (2002). Learning styles of biomedical engineering students. Annuals of Biomedical Engineering, 30(8), 1100-1106. 
Doyle, D., \& Brown, W. (2000). Using a business simu lation to teach applied skills - The benefits and the challenges of using student teams from multiple countries. Journal of European Industrial Training, 24(6-7), 330-336.

Faria, A. J. (2001). The changing nature of business simulation/gaming research: A brief history. Simulation \& Gaming, 32(1), 97-106.

Felder, R. M. (1988). How students learn: Adapting teaching styles to learning styles. Proceedings of Frontiers in Education Conference, Oct 1988, 489-493.

Ghoshal, S., Bartlett, C., \& Moran, P. (1999). A new manifesto for management. Sloan Management Review, 40(3), 9-20.

Gilgeous, V., \& D'Cruz, M. (1996). A study of business and management games. Management Development Review, 9(1), 32-39.

Graf, S., \& Lin, T. K._(2008). The re lationship between learning styles and cognitive traits - Getting additional information for improving student modeling. Computers in Human Behavior, 24(2), 122-137.

Hakkarainen, K., Palonen, T., Paavola, S., \& Lehtinen, E. (2004). Communities of networked expertiseProfessional and educational perspectives. Amsterdam: Elsevier.

Hoffman, T. (2003). Simu lations revitalize e-learn ing. Computerworld, 37(31), 26-27.

Kabeil, M. (2008). Management games in business education. Proceedings of the 15th Scientific Conference for Information Systems and Computer Technology on "E-Learning Communities and Educational Software Development,” Cairo, 26-28 February 2008.

Katzenbach, J. R., \& Smith, D. K. (1993). The wisdom of teams - Creating the high-performance organization. Boston, MA: Harvard Business School Press.

Kim, D. H (1993). A framework and methodology for linking individual and organizational learning: Application in TQM and product development. Ph D Dissertation, Sloan School of Management, Massachusetts Institute of Technology.

Lainema, T. \& Lainema, K. (2007). Advancing acquisition of business know-how: Critical learning elements. Journal of Research on Technology in Education (JRTE), 40(2), 183-198.

Martin, A. (2000). The design and evolution of a simulation/game for teaching information systems development. Simulation \& Gaming, 31(4), 445-463.

Moores, T., \& Chang, J. (2001). Flowers for the world: Developing a business game to support the teaching of IS concepts. Proceedings of AMCIS 2001, Boston MA, Retrieved October 3, 2008, from http://aisel.aisnet.org/amcis 2001/2

Morecroft, J. D. W. (1999). Visualizing and rehearsing strategy. Business Strategy Review, 10(3), 17-32.

Nonaka, I. (1994). A dynamic theory of organizational knowledge creation. Organization Science, 5(1), 14-37.

Senge, P. M. (1997). Looking ahead: Implications of the present communities of leaders and learners. Harvard Business Review, 75(5), 18-32.

Simons, P, Germans, J., \& Ruijters, M. (2003). Foru m for organizational learning: Combining learning at work, organizational learning and training in new ways. Journal of European Industrial Training, 27(1), 41-48.

Stolk, D., A lexandrian, D., Gros B., \& Paggio R. (2001). Gaming and multimedia applications for environmental crisis management train ing. Computers in Human Behavior, 17(5-6), 627-642.

Vincent, A. P. \& Vissers, G. A. (2004) A simple classification model for debriefing management games. Simulation \& Gaming, 35(1), 70-84. 


\section{Biography}

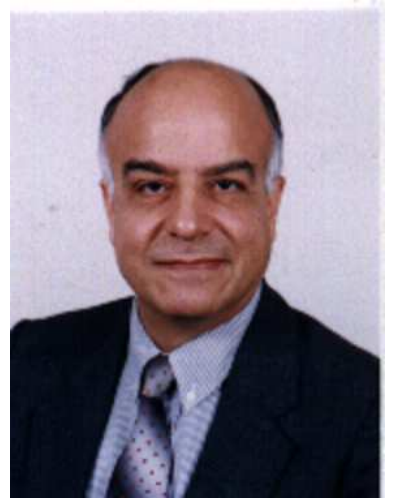

Dr. Kabeil is an Assistant Professor of MIS at the University of Sharjah, UAE, a US Fulbrighter to UC Berkeley 1995/96, and a former Director of the National Operations Research Center of Egypt. He holds a $\mathrm{PhD}$ in Information Systems and Quality Assurance from the College of Engineering, A in Shams University, Egypt, and a MS in Operations Research and Systems Analys is from the Air Force Institute of Technology, Dayton OH, USA. He teaches undergraduate and graduate courses in DSS, Modeling and Simulation, System Dynamics, and Business Process Reengineering. In addition to 2 monographs and 5 chapters in books, he has published over 28 artic les in professional publications. His research interests include DSS, Cris is Management, and IT planning, education and diffusion in developing countries. 